\title{
Coulisses
}

Revue de théâtre

15 | Hiver 1997

Varia

\section{Coulisses au Salon du livre de La Chaux de Fonds}

\section{Raphaël Baud}

\section{OpenEdition}

Journals

Édition électronique

URL : http://journals.openedition.org/coulisses/5165

DOI : $10.4000 /$ coulisses. 5165

ISSN : 2546-9460

\section{Éditeur}

Presses universitaires de Franche-Comté

\section{Édition imprimée}

Date de publication : 1 janvier 1997

Pagination : 67

ISSN : 1150-594X

\section{Référence électronique}

Raphaël Baud, «Coulisses au Salon du livre de La Chaux de Fonds », Coulisses [En ligne], 15 | Hiver 1997, mis en ligne le 26 avril 2019, consulté le 24 septembre 2020. URL : http://

journals.openedition.org/coulisses/5165; DOI : https://doi.org/10.4000/coulisses.5165

Ce document a été généré automatiquement le 24 septembre 2020.

Coulisses 


\title{
Coulisses au Salon du livre de La Chaux de Fonds
}

\author{
Raphaël Baud
}

Du 19 au 22 Septembre 1996 se déroulait à La Chaux de Fonds la deuxième édition suisse du Salon des Régions du Livre, organisée par la Communauté de Travail du Jura et la ville de La Chaux de Fonds. Ce salon rassemblait des éditeurs, auteurs et institutions littéraires des régions frontalières de langue française : Jura suisse, Franche-Comté, Communauté française de Belgique, Val d'Aoste, Ouataouais (Québec). L'université de Franche-Comté faisant partie des exposants, la revue COULISSES y était naturellement présentée, et je fus celui qui la présenta. 


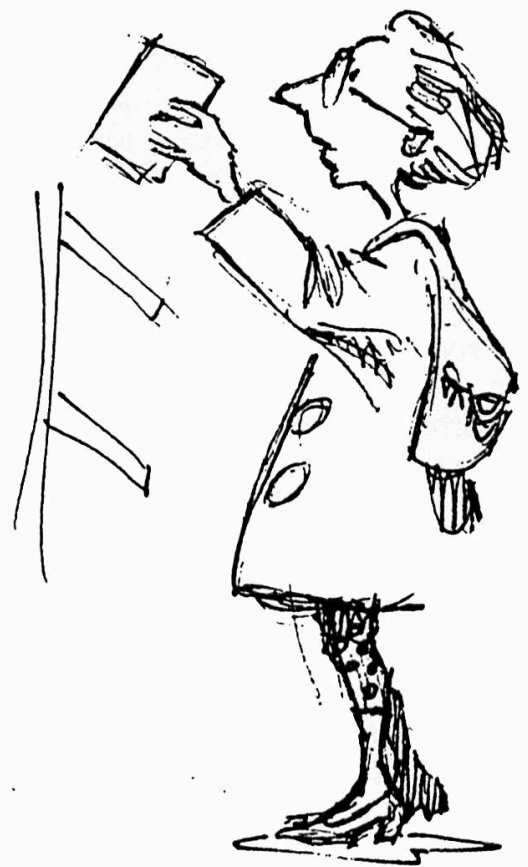

Dessin Raphaël Baud

On aurait pu choisir pour cette paisible mission un vrai amateur de livres, que les ouvrages présentés là-bas auraient réjoui par leur nombre et leur diversité. Mais moi, j'ai le goût de la lecture un peu endormi. Cela garantissait que je ne quitte pas mon stand, jamais distrait par des envies de lire sollicitées de toutes parts.

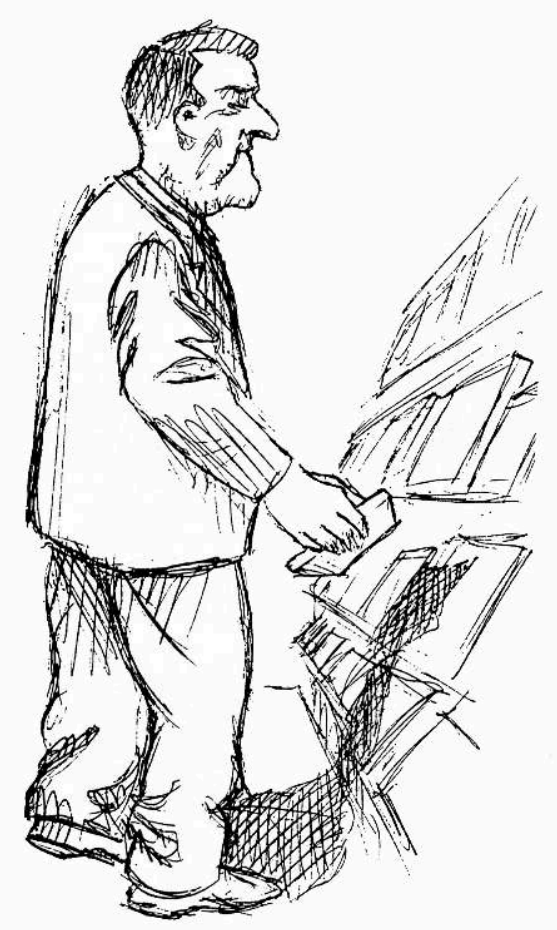

Dessin Raphaël Baud 
3 Pourtant ce fut le contraire qui arriva : Tous ces livres dans tous ces coins, tous ces gens qui tantôt lisaient, tantôt discutaient, doucement, pour ne pas troubler le calme ambiant, ces comédiens qui apparaissaient parfois, haut perchés, pour lire des petits passages à tout le monde, tout cela avait quelque chose d'une église, donnait envie de s'y promener, de feuilleter, de flâner dans les salles, en s'arrêtant de temps en temps devant les dessins de Jean Claverie, des illustrations de livres pour enfants, qui finissaient de remplir le lieu d'une magie silencieuse. 